\title{
A NOTE ON THE CLASSIFICATION OF SOILS ON THE BASIS OF MECHANICAL ANALYSES.
}

\author{
By C. L. WHITTLES, \\ School of Agriculture, Cambridge.
}

(With Eleven Figures.)

\begin{abstract}
Alтнолgн many schemes have been proposed for a classification of soils', not any single one seems to have found general acceptance. It is, however, generally agreed that with any method, a final subdivision based on the texture of the soil is highly desirable, even though it only be the sands, loams, and clays of common parlance. Granted then that a classification based on mechanical analyses is called for-though not necessarily as the primary division into groups-it is here proposed to examine some of the various methods so far put forward for dealing with the results of mechanical analyses. Tables of analytical results in themselves are unwieldy and make decidedly uninteresting reading. The comparison of a large number of soils is a slow and tedious process, if it is accomplished only by a study of the figures.

Hope and Carpenter (22) have devised a method by which one can rapidly refer a soil to one of twelve types. In their classification the particles are classified into four groups, the limiting dimensions of which are given in Table $\mathrm{I}$.
\end{abstract}

Table I. Hope and Carpenter's Classification of Particles.

Limiting diameter in $\mathrm{mm}$.

$\begin{array}{lcc}\quad \text { Ingredient } & \text { Maximum } & \text { Minimum } \\ \text { 1. Coarse sand } & 1.0 & 0.28 \\ \text { 2. Fine sand } & 0.28 & 0.04 \\ \text { 3. Silt } & 0.04 & 0.01 \\ \text { 4. Fine silt and clay } & 0.01 & -\end{array}$

Four broad divisions are distinguished according as one or other of these fractions occurs in the largest percentage. Each of these divisions is subdivided into three classes according as one or other of the three remaining fractions preponderates. Each ingredient is represented by a number $(1,2,3$ or 4$)$, and the type is named by placing the division

1 See Bibliography. 
number first, followed by the appropriate class number. This is summarised in Table II. They point out that each type has a corresponding type into which it can merge by inappreciable degrees, the transformation being effected by interchange in the proportions in the ingredients which are of primary and secondary importance respectively, e.g. 1, 2 to 2,1 . On the other hand, they can diverge far from each other in character. Other relationships are pointed out of which the most important perhaps is the change in the secondary ingredient, as for example from 1,2 to 1,3 .

Table II. Hall and Carpenter's Classification of Soils.

\begin{tabular}{|c|c|}
\hline $\begin{array}{l}\text { Primary ingredient } \\
\text { (division) }\end{array}$ & $\begin{array}{c}\text { Secondary ingredient } \\
\text { (class) }\end{array}$ \\
\hline 1. Coarse sand & $\left\{\begin{array}{l}\text { 2. Fine sand } \\
\text { 3. } \text { Silt } \\
\text { 4. Fine silt and clay }\end{array}\right.$ \\
\hline 2. Fine sand & $\begin{cases}\text { 1. } & \text { Coarse sand } \\
\text { 3. } & \text { Silt } \\
\text { 4. } & \text { Fine silt and clay }\end{cases}$ \\
\hline 3. Silt & $\left\{\begin{array}{l}\text { 1. } \text { Coarse sand } \\
\text { 2. Fine sand } \\
\text { 4. Fine silt and clay }\end{array}\right.$ \\
\hline 4. Fine silt and clay & $\left\{\begin{array}{l}\text { 1. } \text { Coarse sand } \\
\text { 2. Fine sand } \\
\text { 3. Silt }\end{array}\right.$ \\
\hline
\end{tabular}

The earliest reports of mechanical analyses were often illustrated by photographs of the actual fractions obtained. The sand, silt, etc., were placed in small phials of uniform size, and the predominance of the bulk of the material in certain grades served to give a more vivid idea as to the meaning of the figures of the analysis. The method at that time had its value, for the purpose of a mechanical analysis was not so well known then as now. Hilgard's text-book (21) and the early bulletins of the U.S. Department of Agriculture contain illustrations of this type.

It is only a short step from the use of the actual fractions to that of shaded blocks. In Whitney's report on the tobacco soils of Maryland (57) a general summary of the types is given in diagrammatic form in which three grades are distinguished by different shading, viz. sand, silt and clay.

In order to compare several soils or soil types on the same diagram the method of plotting the percentage of each grade against an arbitrary scale of grades has frequently been adopted. Differences are here far more obvious than resemblances, and their correct interpretation is almost as difficult as that of the figures themselves. The plotting of the 
summation percentage against either an arbitrary scale, a natural scale of mean diameters (7), or more conveniently the logarithms of the mean diameters, is to be preferred. By this means a very complete representation of the analysis can be made, and the gradual gradation from type to type clearly seen, but the method becomes unintelligible if any number of soils are plotted on one diagram. A number of soil types are shown in Fig. 1, where the summation percentages are plotted against the logarithms



Fig. 1. Comparison of types by summation curves.

of the mean diameters of the groups, the points so obtained being joined up by a smooth curve. The value $0001 \mathrm{~mm}$. has been taken as the lower limiting value of the dimensions of the clay group. This is purely an arbitrary proceeding. The proportion of "colloid" clay could here be 
shown with great advantage. In this connection the use of ultra-filtration methods might give valuable information.

The curves for the lighter soils rise steeply and then flatten out, those for the heavier soils are flat at first and rise steeply later. Two particular applications of these curves are of importance:

(1) Two soils, analysed according to different systems of grouping of particles may be compared exactly.

(2) The analytical results may be transformed from one system to another by reading off the values at the points at which the curve cuts the mean diameter of the selected classes.

Baker (7) has devised two values for describing a soil from its mechanical analysis plotted in this way. This is of value for catalogue and descriptive purposes, but is not so well adapted for the preparation of drift maps as is the triangular method. In this method only three classes of particles can be considered, which may be conveniently termed Coarse, Medium and Fine respectively. The question now arises as to which two limiting values shall be chosen for the separation of the Medium class from the Coarse and Fine grades respectively. Considering Fig. I we find that:

\section{U.S. Bureau of Soils take $\cdot 03$ and $\cdot 0025$.}

Wilsdon (58) takes $\cdot 025$ and $\cdot 001$.

It is here suggested that, taking into consideration the known properties of the various grades, the curves are best characterised by their intercepts on the lines for $\cdot 12$ and $\cdot 006$. On this basis we have, on the usual English system:

$$
\begin{aligned}
& \text { Coarse (fine gravel + coarse sand) } \\
& \text { Medium (fine sand }+ \text { silt) } \\
& \text { Fine (fine silt }+ \text { clay). }
\end{aligned}
$$

\section{Triangular Methods.}

In the method adopted by the U.S. Bureau of Soils the proportions of clay and silt are plotted along each of two axes at right angles. By joining the 100 points on these lines a right-angled triangle is formed. This is then conventionally divided up into compartments as shown in Fig. 2. The scheme of classification is given in Table III.

Wilsdon has suggested a modification of this method whereby the proportion of the third constituent-the sand-may be read off directly from the diagram. The percentages of sand, silt and clay are plotted on an equilateral triangle. The detailed procedure is given in connection 
Table III. U.S. Bureau of Soil's Classification.

\begin{tabular}{|c|c|c|c|c|c|c|c|}
\hline & $\begin{array}{l}\text { Fine } \\
\text { gravel } \\
2-1 \\
\mathrm{~mm} .\end{array}$ & $\begin{array}{l}\text { Coarse } \\
\text { sand } \\
1-\cdot 5 \\
\mathrm{~mm} .\end{array}$ & $\begin{array}{l}\text { Medium } \\
\text { sand } \\
.5-\cdot 25 \\
\text { mm. }\end{array}$ & $\begin{array}{l}\text { Fine } \\
\text { sand } \\
\cdot 25-\cdot 10 \\
\mathrm{~mm} .\end{array}$ & $\begin{array}{l}\text { Very fine } \\
\text { sand } \\
\cdot 10-\cdot 05 \\
\text { mm. }\end{array}$ & $\begin{array}{l}\text { Silt } \\
\cdot 05-\cdot 005 \\
\mathrm{~mm} .\end{array}$ & $\begin{array}{l}\text { Clay } \\
.005-0 \\
\mathrm{~mm} .\end{array}$ \\
\hline & 1 & 2 & 3 & 4 & 5 & 6 & 7 \\
\hline Coarse sand & \multicolumn{3}{|c|}{$\mid \begin{array}{l}\text { More than } 25 \%(1+2) \\
\quad \text { More than } 50 \%(1+2+\dot{3})\end{array}$} & . & . & \multicolumn{2}{|c|}{\begin{tabular}{c|c}
$0-15 \%$ & $0-10 \%$ \\
Less than $20 \%(6+7)$
\end{tabular}} \\
\hline Medium sand & \multicolumn{3}{|c|}{$\begin{array}{l}\text { Less than } 20 \%(1+2) \\
\text { More than } 20 \%(1+2+\dot{3})\end{array}$} & . & . & $\begin{array}{l}0-15 \% \\
\text { Less than } 20\end{array}$ & $0 \begin{array}{c}0-10 \% \\
0 \%(6+7)\end{array}$ \\
\hline Fine sand & \multicolumn{3}{|c|}{ Less than $20 \%(1+2+3)$} & . & . & \multicolumn{2}{|c|}{\begin{tabular}{c|c}
$0-15 \%$ & $0-10 \%$ \\
Less than $20 \%(6+7)$
\end{tabular}} \\
\hline Sandy loam & \multicolumn{3}{|c|}{ More than $20 \%(1+2+3)$} & - & . & \multicolumn{2}{|c|}{$\begin{array}{l}10 \%-35 \% \\
10 \%-15 \% \\
\text { More than } 20 \%(6+7) \\
\text { Less than } 50 \%(6+7)\end{array}$} \\
\hline Fine sandy loam & \multicolumn{3}{|c|}{ Less than $20 \%(1+2+3)$} & . & . & \multicolumn{2}{|c|}{$\begin{array}{l}10 \%-35 \% \mid 5 \%-15 \% \\
\text { More than } 20 \%(6+7) \\
\text { Less than } 50 \%(6+7)\end{array}$} \\
\hline Loam & - & . & . & . & . & $\begin{array}{l}\text { Less than } \\
55 \%(6) \\
\text { More than } 5\end{array}$ & $\begin{array}{l}15 \%-25 \% \\
\%(6+7)\end{array}$ \\
\hline Silt loam & . & . & . & . & . & $\begin{array}{l}\text { More than } \\
55 \%(6)\end{array}$ & $\begin{array}{l}\text { Less than } \\
25 \%(7)\end{array}$ \\
\hline Clay loam & . & . & . & . & . & \multicolumn{2}{|c|}{$\begin{array}{l}25 \%-55 \% \mid 25 \%-35 \% \\
\text { More than } 60 \%(6+7)\end{array}$} \\
\hline Sandy clay & . & . & . & . & . & $\begin{array}{l}\text { Less than } \\
25 \%(6) \\
\text { Less than } 60\end{array}$ & $\begin{array}{l}\text { More than } \\
20 \%(7) \\
0 \%(6+7)\end{array}$ \\
\hline Silt clay & . & . & . & . & . & $\begin{array}{l}\text { More than } \\
55 \%(6)\end{array}$ & $\begin{array}{l}25 \%- \\
35 \%(7)\end{array}$ \\
\hline Clay & - & . & . & . & . & More than 6 & $\begin{array}{l}\text { More than } \\
35 \%(7) \\
0 \%(6+7)\end{array}$ \\
\hline
\end{tabular}

with a further modification. Soils are classified into fourteen groups, the limiting proportions are given in Table IV, and illustrated graphically in Fig. 3.

Attention is directed to the following considerations in connection with this method:

1. Only a comparatively small area of the whole triangle is employed.

2. The crop types are not so well differentiated as in that of the U.S. Bureau of Soils. 
Table IV. Classification of Soils (Wilsdon).

\begin{tabular}{|c|c|c|c|}
\hline \multirow[b]{2}{*}{ Description } & \multicolumn{3}{|c|}{ Percentage } \\
\hline & $\begin{array}{c}\text { Sand } \\
(+004 \mathrm{~mm} .)\end{array}$ & $\begin{array}{c}\text { Silt } \\
(+0.002 \mathrm{~mm} .)\end{array}$ & $\frac{\text { Clay }}{(-0.002 \mathrm{~mm}}$ \\
\hline $\begin{array}{l}\text { Sand } \\
\text { Sandy loam I } \\
\text { Hëvy sandy loam } \\
\text { Loam I } \\
\text { " II } \\
\text { " III } \\
\text { " IV } \\
\text { Silt" V } \\
\text { Heavy silt loam } \\
\text { Clay loam I } \\
\text { Clay" II }\end{array}$ & $\begin{array}{l}+75 \\
+60 \\
+60 \\
-75 \\
+45 \\
-45 \\
-60 \\
-50 \\
-40 \\
-30 \\
-20 \\
-60 \\
+20 \\
-70\end{array}$ & $\begin{array}{l}-25 \\
-40 \\
-30 \\
-20 \\
+30 \\
+45 \\
+20 \\
+30 \\
+40 \\
+50 \\
+50 \\
-40 \\
+30 \\
-70\end{array}$ & $\begin{array}{l}-25 \\
-10 \\
-20 \\
-30 \\
-10 \\
-10 \\
-20 \\
-20 \\
-20 \\
-20 \\
-30 \\
-30 \\
-30 \\
+30\end{array}$ \\
\hline
\end{tabular}

A + sign is placed before a minimum limit, and a - sign before a maximum.

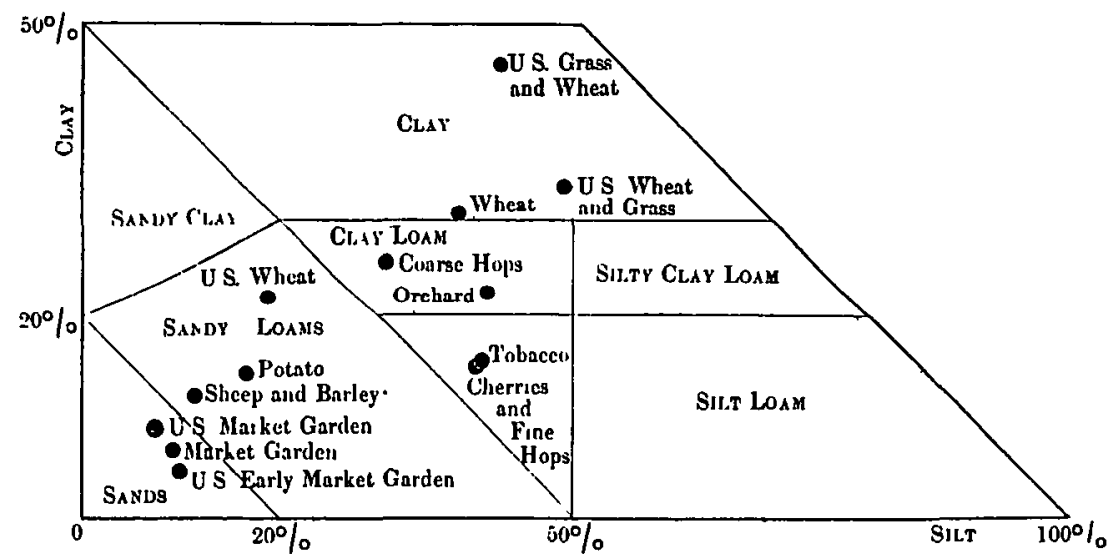

Fig. 2. Comparison of types by U.S. method.



Fig. 3. Comparison of types by Wilsdon's method. 
3. It is difficult to associate each of the three chosen groups with distinct properties in regard to their relation to the movements of water (49).

4. Luxmore(29) has shown that many properties of soils can be correlated with the proportion of particles having a maximum diameter of $0.01 \mathrm{~mm}$.

5. Taking into account the insensible degrees by which any given type merges into another, are we justified in laying down limiting percentages for classes of soils? A soil with a given analysis behaving as a sandy loam in a district of deficient rainfall becomes a loam with a medium rainfall, and a heavy loam with a very high rainfall. The influence of the amounts of organic matter and of calcium carbonate cannot be ignored.

6. Different analysts, working on the same sample of soil frequently -as often as not-obtain discordant results for the clay and fine silt fractions, though they will agree as to the total amount of these two grades present.

7. The rapidity with which a large number of samples can be analysed if the determination of the clay is omitted is an important point.

8. The curves for the summation percentages are better characterised by the proposed limits.

The various limiting diameters of the three classes are shown in Table V.

Table V. Classification of particles.

$\begin{array}{lcccccc}\text { System } & \text { Maximum } & \overbrace{\text { Minimum }}^{\text {Coarse (sand) }} & \text { Maximum } & \text { Minimum } & \text { Maximum } & \text { Minits of diameters in millimetres } \\ \text { Medium (silt) } & \overbrace{\text { Fine (clay) }}^{\text {Linum }} \\ \text { American } & 2.0 & 0.05 & 0.05 & 0.005 & 0.005 & - \\ \text { Wilsdon } & 1.0 & 0.04 & 0.04 & 0.002 & 0.002 & - \\ \text { Proposed } & 3.0 & 0.2 & 0.2 & 0.01 & 0.01 & \text { - } \\ \text { [Or possibly } & .- & 0.2 & 0.2 & 0.02 & 0.02 & \text { - ] }\end{array}$

Atterberg(44) has suggested the limits $\cdot 2, .02$ and $\cdot 002$, and there appears to be fairly strong evidence that a geometrical progression is the type of classification required. As English analysts do not recognise the limit 0.02 , the nearest English point $(0.01)$ has been adopted here provisionally. The result obtained with the types previously considered is shown in Fig. 4. 
The actual procedure adopted for plotting the results can be seen from the following example:



Fig. 4. Comparison of types by proposed method.

In Fig. 5 the side of the equilateral triangle $A B C$ is 100 units, the apices represent 100 per cent. of the respective ingredients.

From $B$ along $B A$ cut off $B P=25.9$ units

$$
\begin{aligned}
& \text { " } A \text { " } A B \text { " } A Q=30.3 \text { " } \\
& \text { "A " } A C \quad \text { " } A R=28.9 \text { ", }
\end{aligned}
$$

From $P, Q$ and $R$ draw $P X, Q Y$ and $R Z$ parallel with $B C, A C$ and $A B$ respectively to form the triangle $p q r$.

Then any point on the line $P X$ represents 25.9 per cent. of the coarse particles, on $Q Y 30.3$ per cent. of the medium particles, and on $R Z 28.9$ per cent. of the fine particles. 
Then the centre $S$ of the triangle $p q r$, obtained by bisecting the base angles is the required point. This construction avoids the necessity for raising the percentages arithmetically so that they total 100 . In general they will be less than 100, for the losses on solution and ignition are not included in the amounts plotted.

Soils with a high content of organic matter or of calcium carbonate cannot be compared by their position on the triangle alone. By the employment of an arbitrary colour scale, the organic matter content, or the acidity expressed in terms of titration values or of hydrogen ion concentration could be shown simultaneously with its opproximate mechanical analysis. Rainfall and other climatic data are obviously open to a similar method of treatment.

In order that the position of a point on the diagram may be rapidly interpreted, a diagram showing the proportions of each of the three ingredients present, by steps of 10 per cent. has been prepared. By super-imposing this on any of the soil diagrams the limits of the groups can rapidly be read off.

The amount of variation permissible in a mechanical analysis for survey purposes has been investigated by Robinson(39). The analyses of the two yields, $(a)$ uniform, $(b)$ too variable, are shown in Fig. 5. Attention is drawn to this in order that an idea may be obtained as to the value that is to be assigned to any amount of scatter in a diagram.

The general arrangement of the soil types is indicated in Fig. 4. The triangle has been divided up into three main divisions (marked in solid lines) according as one or other of the three ingredients predominates. Each division is subdivided into two classes (by dotted lines) according as one or other of the remaining two constituents is in excess. The interrelationship between class and class is thus proportional to the length of the dividing line. They may merge into one another or diverge widely. For convenience of reference the classes may be named $A_{B}, B_{A}, B_{C}$, $\mathrm{C}_{B}, \mathrm{C}_{\mathrm{A}}$ and $\mathrm{A}_{\mathrm{C}}$, respectively as shown.

Fig. 6 shows a number of wheat soils from almost every geological formation. It will be noticed that they tend to be more or less concentrated around those selected by Hall and Russell as typical. The lighter soils of Norfolk on which wheat is grown, though the soils are not particularly well adapted to the crop, merge into the typical wheat group, which apparently lies near the boundary of $B_{C}$ and $C_{B}$. The soils in $C_{B}$ are on the whole more typically grass than arable $(12,16,17,19,20,29$, $31,36,40)$.

Barley soils are illustrated in Fig. 7. The crop is grown on soils of the 
C. L. WhitTles

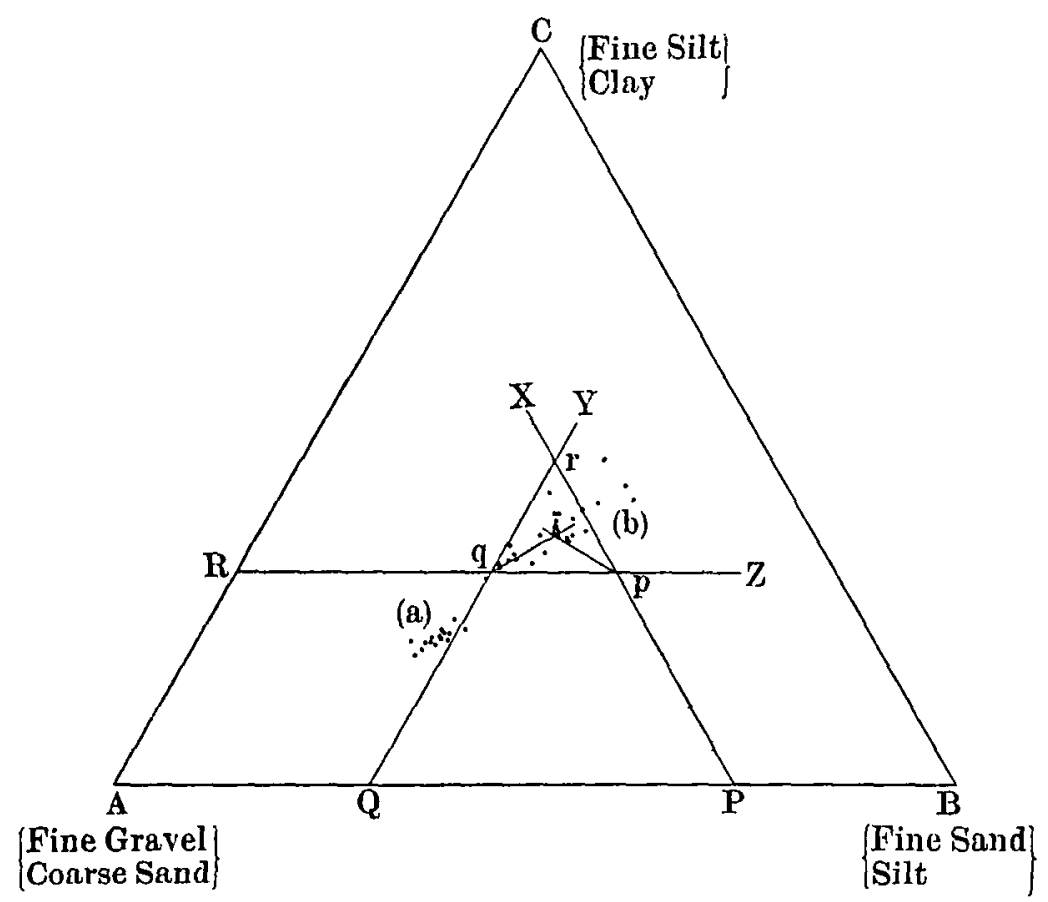

Fig. 5. Method of plotting, and degree of variation permissible.

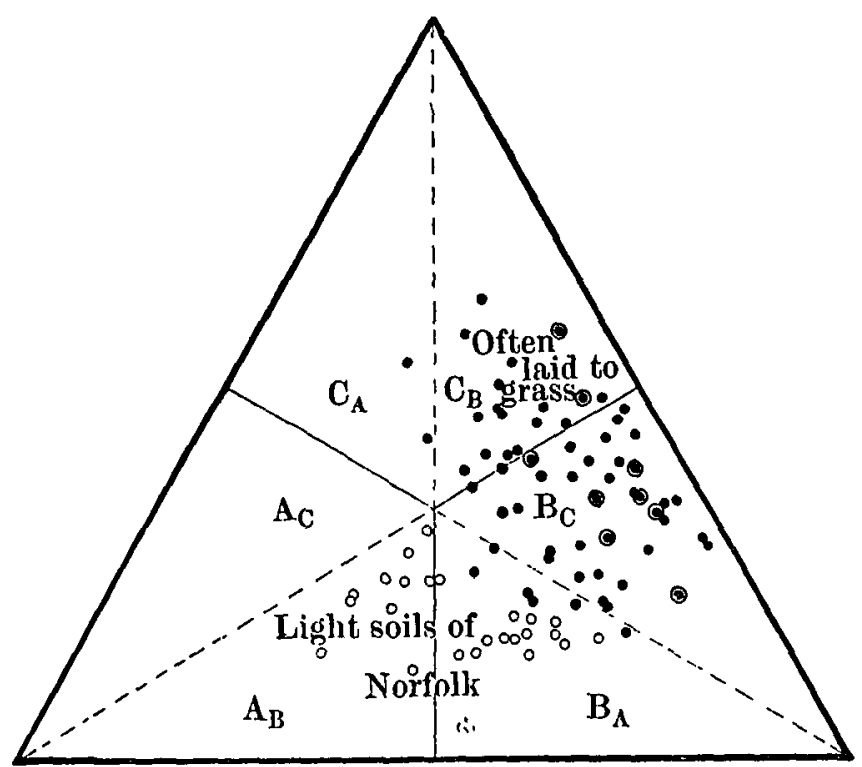

Fig. 6. Wheat solls. 


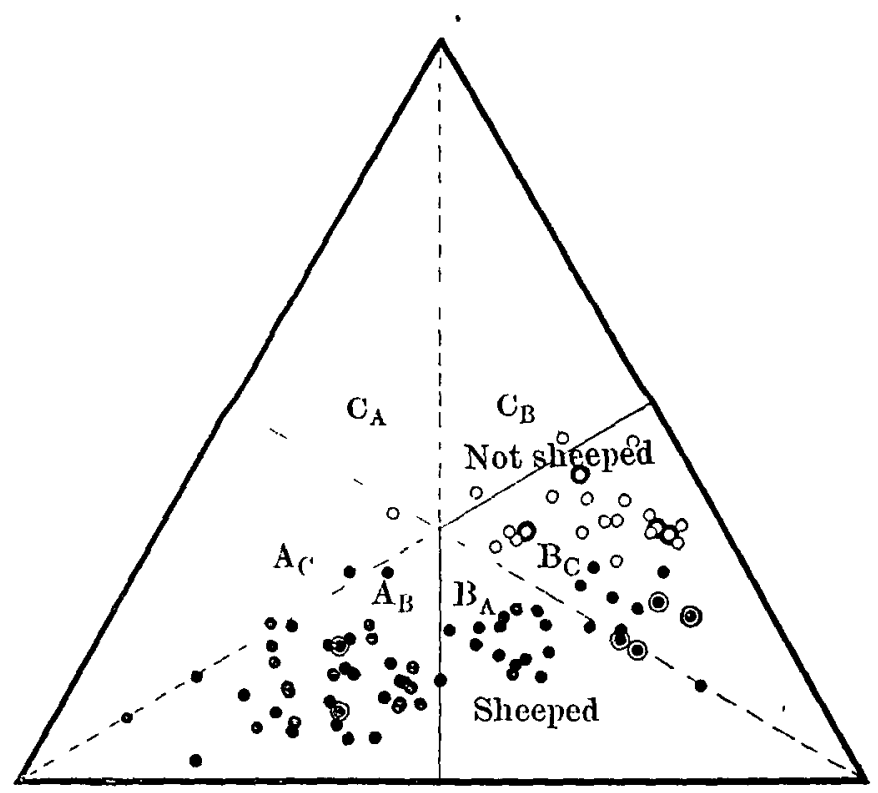

Fig. 7. Barlẹ soils.



Fig. 8. Hop soils. 
- Typical Soils, quoted by Hall and Russell

- Other typical soils, from rarious sources

- Soils on which crop is grown, though soil not really typical of the crop

- Ditto (quoted by Hall and Russell)

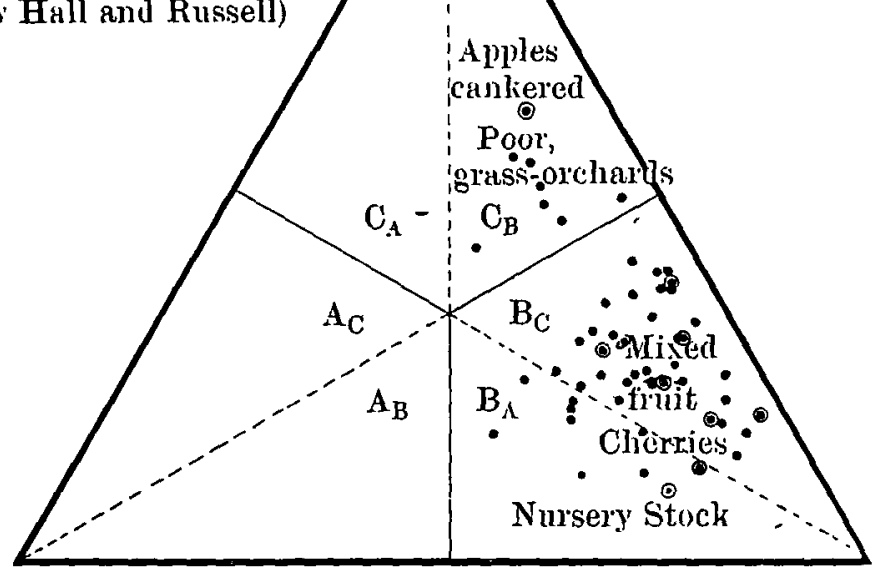

Fig. 9. Orchard soils.

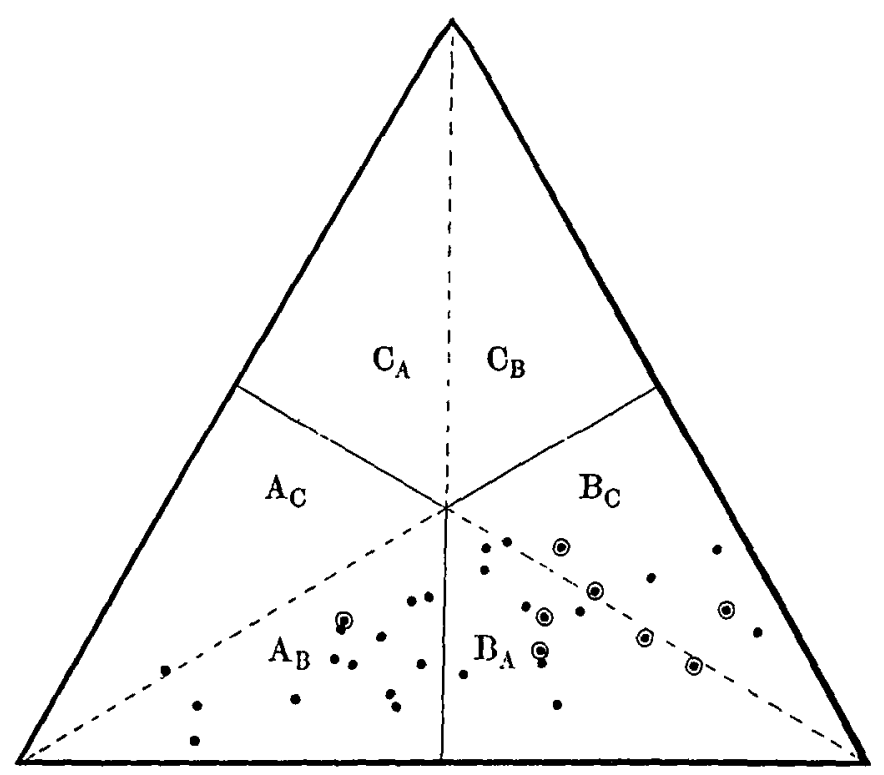

Fig. 10. Potato soils. 
three classes $A_{B}, B_{A}$ and $B_{C}$, but it is only the lighter soils of the latter class that can carry sheep.

Hop soils are illustrated in Fig. 8, and Orchard soils in Fig. 9. The comparison of these two types made by Hall and Russell(19) is clearly illustrated. The orchard soils in $\mathrm{C}_{\mathrm{B}}$, apart from the extreme case quoted by Hall and Russell from the Weald Clay, are all grassed orchards, and according to the Bristol Reports $(13,14,55)$ suffer from canker to a greater or less extent. Evidently these soils are really too heavy for fruit.

In Fig. 10 a number of potato soils are shown. The limiting factor for a potato soil, low content of coarse silt, is not brought out very well by this method $(1,19,20,41)$.

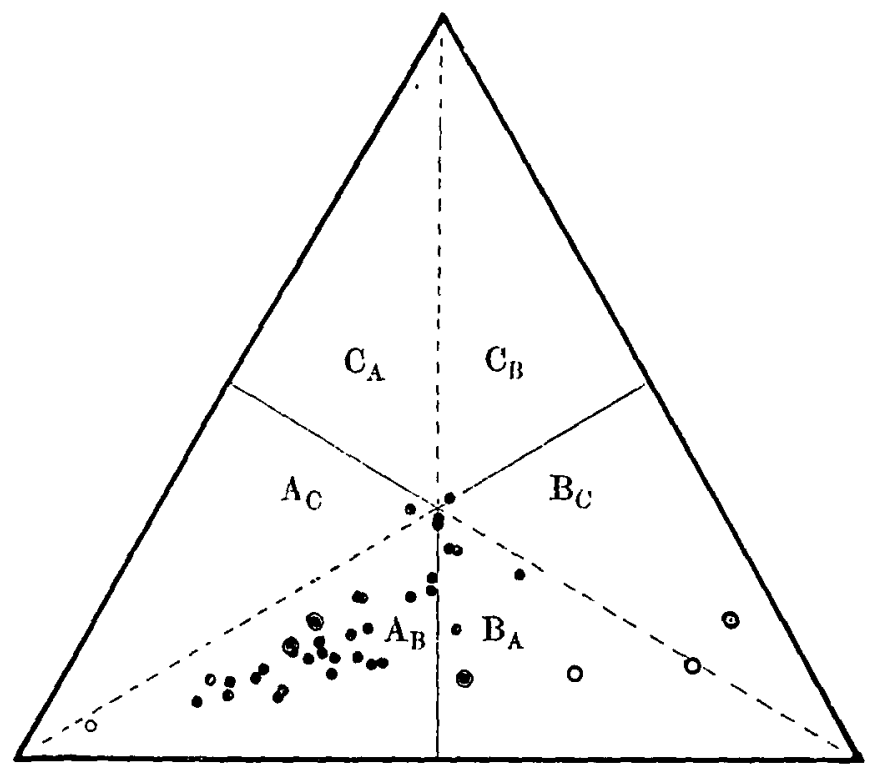

Fig. 11. Market garden soils.

The Biggleswade Market Garden soils (35) which are most typical are shown in Fig. 11. Those which have been utilised on account of economic reasons have been omitted. Hall and Russell's Merton Alluvial soils approximate more closely to the Biggleswade type than does the Weybridge, but these are both more of the Market Garden type than the Bagshot Windlesham and the Thanets from Swanley and Greenhythe. 


\section{Application to the Preparation of Maps.}

If each of the three primary colours be taken to represent one of the three constituents (Coarse, Medium, and Fine), then to any position on the triangle is a corresponding definite colour, produced by a combination of the three primary colours in the same proportions. Any desired degree of differentiation may be attained by using a sufficiently large number of combinations. Steps of 5 per cent. would give 231 types, and this would be sufficiently accurate for all purposes, as will be seen from a consideration of Fig. 5. For the preparation of the drift maps of a district, steps of 10 per cent. giving 66 types would probably be sufficient. The proportion of stones and gravel, chalk, organic matter, etc., could be shown by dots or shading. Maps of the soil and subsoil prepared on these lines would be of great value.

In conclusion, the writer begs to tender his thanks to all those who have supplied him with data and other help.

\section{A Bibliography on Soll Classification, with data for soll types.}

(1) Ashiy, S. F. (1905). A Contribution to the study of Factors affecting the Quality and Composition of Potatoes, Jour. Agric. Sci. 1, 350.

(2) Atrterbero, A. (1908). On Methods of clay analysis. K. Landtbr. Akad. Handl. och Tidskr. 47, Nos. 5-6.

(3) - (1909). The constituents of mineral soils; the analysis, classification and principal properties of clay soils. Compt. Rend. Conf. Internat. Agrogéol. [Budapest], 1.

(4) - (1912). Mechanical soil analysis and classification of Swedish mineral soils. K. Landtbr. Akad. Handl. och Tidskr. 51, No. 6; Internat. Mitt. Bodenk. 2, No. 4.

(5) - (1916). The classification of humus-free and humus-poor mineral soils of Sweden according to their consistencies. Internat. Mitt. Bodenk. 6.

(6) Atterbera, A. and Johansson (1916). The classification of the mineral soils of high humus content of Sweden. Internat. Mitt. Bodenk. 6.

(7) B $\triangle \mathrm{KER}, \mathrm{H}$. A. (1920). Investigation of the mechanical constitution of loose arenaceous sediments by the method of elutriation. Geological Magazine, 57, Nos. 7-9.

(8) BJ $\phi_{\text {RLYzKE }}$, K. O. (1901-2). On the Classification of Soils. Berg. Norges. Landbr. Hoiskolen Virks, App.

(9) Cholinory, E. von (1909). Soil type as determined by climatic zones. Compt. Rend. Conf. Internat. Agrogéol. [Budapest], 1, 163-176.

(10) Correy, G. N. (1916). The present status and future development of soil classification. - Jour. Amer. Soc. Agron. 8, 239.

(11) Fuprin, E. 0. (1911). The practical classification of soils. Proc. Amer. Soc. Agron. 3, $70-89$.

(12) Foremax, F. W. (1907). Soils of Cambridgeshire. Jour. Agric. Sci. 2, No. 2, 161.

(13) Grmminaham, C. T. (1912). Annual Report of the National Fruit and Cider Institute. 
(14) Grmmingham, C. T. and Grove (1919). Annual Report of the National Fruit and Cider Institute.

(15) GurNkA, K. (1914). Die Typen der Bodenbildung (Berlin).

(16) GOODWT, W. The Soils of Nottinghamshire.

(17) HAGGARD, H. R. (1902). Rural England. (Maps of soils and crops.)

(18) Hatr, A. D. (1912). The value of soil analyses to the farmer. Jour. Roy. Agric. Soc. 73.

(19) HALL, A. D. and Russeld, E. J. (1911). The Agriculture and Soils of Kent, Surrey and Sussex.

(20) _- (1911). Soil Surveys and Soil Analyses. Jour. Agric. Sci. 4, No. 2, 182.

(21) Hula Rd (1906). Soils.

(22) Hope, G. D. and CARPENTRR, P. H. (1915). Suggestions for the manurial treatment of tea soils. (Indian Tea Association, Calcutta.)

(23) INKey, B. DE (1910). Nomenclature and classification of soil types. II Conf. Agrogéol. Internat. Stockholm, Résumé (1).

(24) Kossowitsch (1912). Die Schwarzerde.

(25) Kossovich, P. (1906). The genesis of soils and the principles of a genetic soil classification. Zhur. Opuitn. Agron. (Russ. Jour. Expt. Landw.), 7, No. 4, 478.

(26) - (1910). The soil forming processes and the main principles of soil classification. Zhur. Opuitn. Agron. (Russ. Jour. Expt. Landw.), 11, No. 5.

(27) Lagatu, H. (1903). L'étude des terres et les cartes agronomiques (Montpelier).

(28) - (1905). Classification and nomenclature of soils according to mineralogical constitution. Compt. Rend. Acad. Sci. (Paris), 141, No. 6, 363.

(29) LUXMOORE. Soils of Dorset.

(30) MURGoccr. Die Bodenzonen Rumäniens.

(31) NEWMAN, L. F. (1912). Soils and Agriculture of Norfolk. Trans. Norfolk and Norwich Naturalists' Society, 9, 349.

(32) Pendleton, R. L. (1919). Are soils mapped under a given type name by the Bureau of Soils Method closely similar to one another? Univ. Cal. Pubs. Agr. Sci. 3, No. 12.

(33) RAMANN, E. (1920). Bodenkunde (Berlin).

(34) - (1918). Bodenbildung und Bodeneinteilung (Berlin).

(35) RIGG, T. (1916). Soils and Crops of the Market Garden District of Biggleswade. Jour. Agric. Sci. 7, No. 4, 385.

(36) RobINsow, G. W. (1913). Soils of Shropshire.

(37) - (1917). Studies on the Palaeozoic soils of North Wales. Jour. Agric. Sci. 8, No. 3,338 .

(38) Robinson, G. W. and Hrll (1919). Further Studies on the Palaeozoio soils of North Wales. Jour. Agric. Sci. 9, No. 3, 259.

(39) Robinson, G. W. and Lloyd, W. E. (1915). On the Probable Error of Sampling in Soil Survey. Jour. Agric. Sci. 7, No. 2, 144.

(40) Ruggo, L. H. Farming of Dorsetshire. Jour. Royal Agric. Soc. 15, 389.

(41) Russell, E. J. (1921). Soil Conditions and Plant Growth.

(42) SAUER, C. 0. (1918). A soil classification for Michigan. Ann. Rpt. Mich. Acad. Sci. 20.

(43) Schreiner, O. and Skinner, J. J. (1918). The Triangle System for fertilizer experiments. Jour. Amer. Soc. Agron. 5, No. 10, 225.

(44) Schucht, F. (1914). Report of the meeting of the International Commission for the mechanical and physical examination of soil. Internat. Mitt. Bodenk. 4, No. 1.

(45) Sibirtzev (1895). Genetic classification of soils. Memoirs of the Instit. of Agric. and Forest. at Novo-Alexandria, Government of Lublin, 9, pt. 2, 1-23. 


\section{L. WhitTles}

(46) Sibirtzev (1897). L'étude des sols de la Russie. Congrès Géologique Internationale, St Pétersbourg.

(47) - (1898). Brief survey of the chief soil types of Russia. Memoirs of the Instit. of Agric. and Forest. at Novo-Alexandra, Government of Lublin, 11, pt. 3.

(48) Sinva, L. A. Rebelio da (1907). Classification of Soils. Rev. Agron. [Portugal], 5, No. 10, 294-301.

(49) Smrth, A. (1917). Relation of the Mechanical Analysis to the Moisture Equivalent of Soils. Soil Science, 4, 471.

(50) Teввutт, J. (1920). French Agricultural Soil Maps. Jour. Min. Agric. 27, No. 1.

(51) Trerrz, P. (1909). What is weathering? Compt. Rend. Conf. Internat. Agrogéol. [Budapest], 1, 131-161.

(52) Tulatkopp, N. (1908). Genetic Classification of Soils. Joutr. Agric. Sci. 3, No. 1, 80.

(53) Tomr, G. (1910). Mechanical analysis and cartographic grouping of rocks and soils. Ezheg. Geol. i. Min. Rossii, 12.

(54) Vysotskr, G. N. (1906). On climatic basis of classification of soils. Pochvooyedyenie [Pédologie], pp. 1-18. Ahs. in Zhur. Opuitn. Agron. [Russ. Jour. Expt. Landw.], 8 (1907), 536.

(55) WALLACE (1920). Annual Report National Fruit and Ctder Institute.

(56) WerbULL, M. (1907). An investigation of soils of Southern Sweden. K. Landlbr. Akad. Handl. och Tidskr. 46, Nos. 2-3, 107-178.

(57) Writney (1892). Report on Soils of Maryland. U.S. Weather Bureau Bull. No. 4.

(58) Wrisdon, B. H. (1919). The Need and Objects of a Soil Survey in the Punjaub. Agric. Jour. of India, 14, pt. 2, 281.

(Received February 22nd, 1922.) 